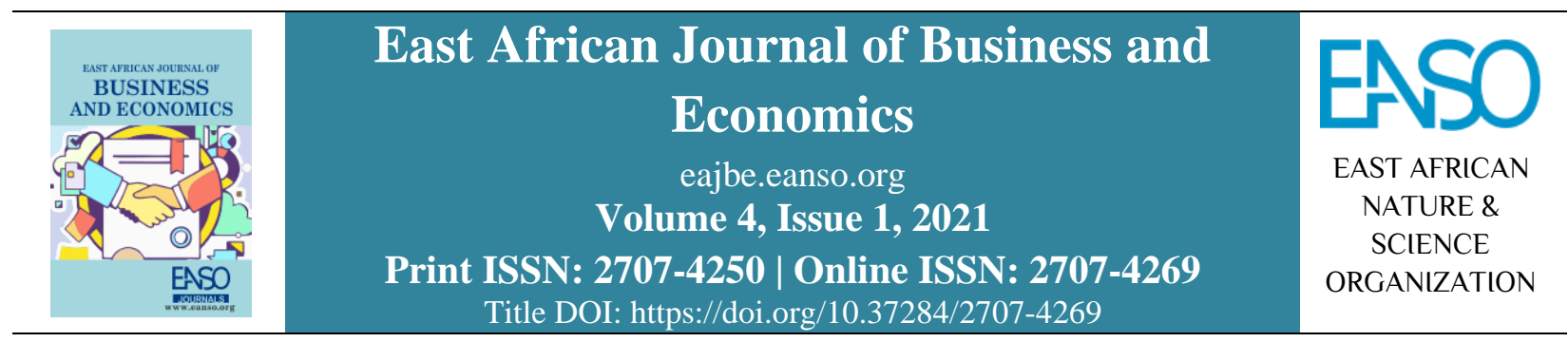

Original Article

\title{
Influence of Enterprise Strategy Typologies on Youth Livelihood Outcomes in Kenya.
}

\author{
Christine W. Njuguna, $P h D^{1} \&$ Phoebe Ndayala Didi, $P h D^{2}$ \\ ${ }^{1}$ Kenyatta University, P. O. Box 43844-00100, Nairobi, Kenya. \\ * ORCID: https://orcid.org/0000-0001-71733-0498; Correspondence email: kristinenjuguna@ gmail.com.
}

Article DOI: https://doi.org/10.37284/eajbe.4.1.513

\section{Date Published: ABSTRACT}

20 December 2021 Youth unemployment and underemployment are grave social issues prevalent in developing countries. Ensuring that youth attain productive ends or

Keywords: sustainable livelihood outcomes is a major concern of many governments, organisations and institutions globally. The purpose of the study was to

Enterprise Strategies,

Livelihood Outcomes, determine the influence of enterprise strategy typologies on youth livelihood outcomes in Kamukunji Sub-County, Nairobi County, Kenya. Anchored on

Department for International Development livelihoods framework and the Youth Groups, General Systems Theory, the study applied a cross-sectional survey research

Kenya. was conducted using descriptive frequencies and inferential statistics, namely Chi-square, Z statistic and Ordered Logistic Regression. Findings from inferential statistics established that regardless of the livelihood strategy typology youth adopted (business, wage employment, homemaking, arts \& talents and agriculture-based), the livelihood outcomes did not differ significantly. As a group, livelihood strategy typology did not jointly determine youth livelihood outcomes. However, specific enterprise strategies whose parameters attained statistical significance were: wage employment $(\beta=0.74$, $\mathrm{p}<0.05)$ and arts/talent $(\beta=0.26, \mathrm{p}<0.05)$ which were important in predicting the level of YLO level. The study recommends that State and Non-State actors should implement elaborate and expansive business incubation and mentorship programs for youth. To improve livelihood outcomes for all youth, development agencies should ensure that youth-focused interventions target all typologies of enterprise strategies undertaken by the youth.

\section{APA CITATION}

Njuguna, C. W., \& Didi, P. N. (2021). Influence of Enterprise Strategy Typologies on Youth Livelihood Outcomes in Kenya. East African Journal of Business and Economics, 4(1), 106-116. https://doi.org/10.37284/eajbe.4.1.513

\section{CHICAGO CITATION}

Njuguna, Christine W, and Phoebe Ndayala Didi. 2021. "Influence of Enterprise Strategy Typologies on Youth Livelihood Outcomes in Kenya". East African Journal of Business and Economics 4 (1), 106-116. https://doi.org/10.37284/eajbe.4.1.513.

106 | This work is licensed under a Creative Commons Attribution 4.0 International License. 


\section{HARVARD CITATION}

Njuguna, C. W., \& Didi, P. N. (2021) "Influence of Enterprise Strategy Typologies on Youth Livelihood Outcomes in Kenya", East African Journal of Business and Economics, 4(1), pp. 106-116. doi: 10.37284/eajbe.4.1.513.

\section{IEEE CITATION}

C. W. Njuguna, \& P. N. Didi. "Influence of Enterprise Strategy Typologies on Youth Livelihood Outcomes in Kenya", EAJBE, vol. 4, no. 1, pp. 106-116, Dec. 2021.

\section{MLA CITATION}

Njuguna, Christine W, and Phoebe Ndayala Didi. "Influence of Enterprise Strategy Typologies on Youth Livelihood Outcomes in Kenya". East African Journal of Business and Economics, Vol. 4, no. 1, Dec. 2021, pp. 106-116, doi:10.37284/eajbe.4.1.513

\section{INTRODUCTION}

The Department for International Trade hereafter referred to as DFID (1999) Livelihoods Framework highlights key influential factors such as assets or capitals, vulnerability context, transformation structures and processes all of which affect the choice of enterprise strategies undertaken. According to the framework, for individuals to earn a living, they must methodically utilise their livelihood assets or capital in the contexts of the institutional structures or arrangements they find themselves in. Enterprise strategies encompass the synergising a number and combination of assets, choices and activities within a set of institutional contexts to attain productive ends or outcomes (DFID, 1999). Serrat (2017) argues that livelihoods are presumed to be sustainable if they can cope with and recover from shocks and stress, sustain and build up assets, capabilities and activities while preserving the natural resource base. Livelihood outcomes comprise: more sustainable use of natural resource base, reduced vulnerability, recovered human dignity, augmented income, food security and wellbeing (Serrat, 2017; DFID, 1999). Arkoh (2019) demonstrated that the extent and depth of assets or capital that an individual can access would often influence their abilities, capabilities, and strategies for pursuing employment and productivity. Moreover, the institutions, systems, processes and policies, existing in a place will also define the extent to which opportunities are available for people eligible to take them up. Access to basic infrastructure and productive assets among the youth remains a challenge. There exists a vulnerability context which consists of the external environment in which people pursue their livelihoods (Serrat, 2017; DFID, 1999). This context can destroy, create or affect asset availability as well options of enterprise strategies available to individuals.

The greatest challenges to desirable livelihood outcomes faced by urban youth in the $21^{\text {st }}$ Century include unemployment, underemployment and working poverty. According to the UN-Habitat (2013), 90 million youth are unemployed (47\% of the total number of unemployed persons globally) with 300 million as working poor in unskilled, insecure employment under unsatisfactory conditions. According to an ILO report, predictions indicate the rate of unemployment amongst all youth will double between 2010 and 2035 (Elder and Rosas, 2015). According to United Nations Development Programme [UNDP, 2010), worldwide, $85 \%$ of new employment opportunities are from slum-based informal economies, consequently forcing the youth into low-income jobs. This is the case for a large number of youths in many African countries such as Kenya. Consequently, many urban youths adopt different enterprise strategies to achieve desired livelihood outcomes and are mainly engaged in the informal sector. All this occurs in a context that may differ from one youth to another.

The United Nation's World Youth Report 2018 affirms that youth account for $16 \%$ of the total world population and of these 1.2 billion, 62 million are not in education or employment with 75 million having undergone training but lacking employment opportunities (United Nations, 2018). The report 
further states that youth in the world is approximately 3 times more likely to be jobless than older people, mainly attributed to the rapid youth bulge that is not in tandem with most nations' economic growth (United Nations, 2018; ILO, 2020). The ILO Centenary Declaration for the Future of Work, embraced by ILO constituents on the event of the Centenary of the International Labour Organization (June 2019), calls upon the ILO to direct its efforts to, inter alia, "developing effective policies aimed at generating full, productive and freely chosen employment and decent work opportunities for all, and in particular facilitating the transition from education and training to work, with an emphasis on the effective integration of young people into the world of work" (ILO, 2020). Various countries and international organisations have set up varied strategies to address the problem of lack of engagement in productive activities and youth poverty. In June 2012, the ILO adopted a resolution calling for immediate, targeted and renewed action to tackle the youth unemployment crisis. The resolution proposes the adoption of a portfolio of tested measures in five areas: macro-economic policies, employability, labour market policies, youth entrepreneurship and rights (ILO, 2012). As part of efforts to achieve Sustainable Development Goal 8 to "[promote sustained, inclusive and sustainable economic growth, full and productive employment and decent work for all", the international community was called upon to, by 2020, (i) develop and operationalise a global strategy for youth employment and (ii) substantially reduce the proportion of youth not in employment, education or training (NEET); (ILO, 2020). Despite all these efforts set up at national and global levels, the ILO 2020 report statistics indicate one-fifth of young people currently have NEET status, which means they are neither gaining experience in the labour market, nor receiving an income from work, nor enhancing their education and skills.
Youth unemployment is one of the biggest challenges in developing countries Kenya included. According to the 2019 Kenya Census data, $5,341,182$ or $38.9 \%$ of the $13,777,600$ young Kenyans are jobless (Kenya National Bureau of Statistics, 2019). This is worrying considering DFID 2017 estimates indicate Kenya's youth population is at nearly 10 million, more than $20 \%$ of its overall population. Kenya is currently experiencing a so-called 'youth bulge' (defined as a situation when at least $20 \%$ of a country's population is between the age of 15 to 24) (DFID, 2017). Despite the many state-initiated policy efforts, youth unemployment continues to escalate. With 500,000 to 800,000 young Kenyans entering the job market each year, its economy has not been able to provide the necessary amount of employment opportunities - formal and informal alike (DFID, 2017). This situation calls for more concerted efforts in promoting enterprise diversification among the Kenyan youth. The situation is worsened by the youth bulge and ruralurban migration of youth that diminish the available opportunities. This is more so in urban areas.

According to the Kenya National Youth policy, the Kenyan youth face myriad of challenges: they include unemployment, restricted access to opportunities and services such as quality education, health care, training, recreation and peer pressure that sometimes pushes them into criminal activities (Rakodi, 2016). The deficiency of opportunities for employment has resulted in many youths seeking refuge in the sprawling informal sector whose performance mainly depends on the health of the economy (Marable, 2015). This has been attributed to, among other factors the education system's failure to equip youth with skills and disposition to seek livelihoods through enterprises and self-employment, lack of positive role models, lack of family and community support, positive spaces, political manipulation and mistrust. Various factors have continued to negatively impact youth livelihood outcomes in Kenya. Young 
workers continue to face high rates of poverty and are increasingly exposed to non-standard, informal and less secure forms of employment (ILO, 2020). In addition, increasing unemployment, underemployment and disillusionment have disproportionately had a high impact on the youths and their livelihoods outcomes (Njonjo, 2010). To make matters worse, Kenya's economy has presented volatile yet comparably high growth rates in the last two decades. However, this generally positive macro-economic development has not translated into benefits for its youth (DFID, 2017). The result of this has led to many youths pursuing precarious livelihoods due to poverty. Education is imperative for arming people for modern-day wage employment, equipping individuals with capabilities to change employment patterns and is commonly associated with improved productivity and earnings (Filmer and Fox, 2014).

For many rural youths, underemployment in low productivity household-based activities are their main challenge as compared to unemployment among the educated urban youth. Moreover, unemployment for long durations deters individuals from looking for opportunities they have been trained for. In Kenya, there is a growing trend that educated youth faced with the uncertainty surrounding formal employment venture into farming as an alternative livelihood strategy (Mwuara, 2015). In addition, due to low levels of income and unemployment, many urban youths have been forced to self-employment or be "entrepreneurs by necessity" rather than "entrepreneurs by choice". Others get employment in family-owned small low productive businesses which do not offer secure income. The youth thus struggle in the informal economy faced with numerous challenges of lack of entrepreneurial skills with little or no access to affordable finance or business development services. Unemployment leads to the inclination for people to participate in undesirable and risky activities to sustain livelihoods. Youth operate in a context where they are faced with economic, social and political challenges (Republic of Kenya 2011a; 2011b), all of which have an impact on their livelihood outcomes. The study, therefore, seeks to establish the influence of enterprise strategies pursued by the youth in Kamukunji and their influence on their livelihood outcomes.

\section{MATERIALS AND METHODS}

The survey was carried out among 201 male and female youths aged between 18 to 35 years randomly selected from the registered youth selfhelp groups in Kamukunji, Nairobi PLWHA in Nairobi County, Kenya. The inclusion criteria were members of registered youth groups which should have been in operation for at least three years since inception. The groups could be of mixed gender or constitute members of either gender only (males or females). It was assumed that by their third year, the groups had developed a clear vision, leadership structure after going through the stages of forming, storming, and norming and were now at the performing stage in the group stage development cycle (Tuckman, 1965). Also, by this time, many groups are able to qualify for support such as loans from financial institutions and devolved funds from the government. This was in addition to the groups being able to give a vivid account of their group activities. The study adopted a cross-sectional survey research design to gather data. A structured questionnaire and focus group discussion guide were used to collect data on enterprise strategies before and after joining the youths' groups as well as the influence of the strategies on their livelihood outcomes. Analysis was conducted using descriptive frequencies and inferential statistics, namely Chi-square, Z statistic and Ordered Logistic Regression.

The independent variables were represented by the enterprise strategies adopted by youth. These included business, employment wage, household duties, art/talent and agriculture. 
Categorisation of Respondents by their Livelihood Outcome

The dependent variable was Youth Livelihood outcome measured by fifteen questions along a 5point scale. Scores of responses to fifteen questions along a 5-point scale were calculated for the purpose of establishing the dependent variable (youth livelihood outcomes). The questions assessed the extent to which youth had experienced various aspects of their livelihoods in the last year. Responses on the scale were coded as: " $1=$ None at all", " $2=$ Little Extent", " $3=$ Moderate Extent", "4=Large Extent", and "5=Very Large Extent". The lowest and highest possible scores an individual could have achieved for the 15 questions were 1 and 75 , respectively.

Based on this approach, youth who scored 1-25 points were categorised as belonging to the survival level of YLO; those who attained 26-50 points were categorised as belonging to the security level of YLO; respondents who attained 51-75 points were categorised as belonging to growth level of YLO. From this categorisation, the study sought to determine the frequency of youths across the levels and established that 105 (52\%) out of sampled youth attained survival level of youth livelihood outcomes, whereas $35(18 \%)$ and $61(30 \%)$ of them attained security and growth level of youth livelihood outcomes respectively.

\section{Research instruments}

An interviewer-administered structured questionnaire targeting the youth was administered. The structured questionnaire helped to collect information on the enterprise strategies adopted by the youth in the study. The FGD guide targeted officials and ordinary members of youth groups.
The FGD guide allowed for the divergence of views since group dynamics enthused new perspectives among participants (Stewart, Shamdasami and Rook, 2006; Krueger, 2008). Moreover, the youth group FGD guide sought insights into opinions, concerns, perceptions and attitudes of the members' livelihoods strategies, challenges facing youth groups, financial behaviour, knowledge, access and utilisation of youth-focused interventions in the study area.

Quantitative data was analysed by Statistical Package for Social Sciences (version 20) using descriptive frequencies and inferential analysis. Descriptive summary statistics constituted measures of central tendency to include frequencies, means, medians and standard deviation. Inferential statistics constituted Z-Statistic and Ordinal Logistic Regression which was used for hypothesis testing. Regression analysis was used to establish causal relationships, the direction of influence and magnitude between the dependent variable (youth livelihood outcomes) and the independent variable enterprise strategies adopted by youth.

Ethical approvals were obtained from the relevant authorities and informed written consent was granted by the research participants prior to the commencement of the study.

\section{RESULTS}

\section{Typologies of Enterprise strategies Before Joining Youth Groups}

Business, wage employment, homemaking, arts/talent-based and agriculture-based activities as shown in Table $3 \backslash$, were found to be the primary enterprise strategies sorted by youth before their membership into youth groups. 
East African Journal of Business and Economics, Volume 4, Issue 1, 2021

Article DOI: https://doi.org/10.37284/eajbe.4.1.513

Table 1: Livelihood Strategy Before Joining Youth Group by YLOs

\begin{tabular}{|c|c|c|c|c|c|c|c|}
\hline \multirow{2}{*}{ Core livelihood strategy } & \multicolumn{2}{|c|}{ Survival } & \multicolumn{2}{|c|}{ Security } & \multicolumn{2}{|c|}{ Growth } & \multirow{2}{*}{ Total } \\
\hline & $\mathbf{n}$ & $\%$ & $\mathbf{N}$ & $\%$ & $\mathbf{N}$ & $\%$ & \\
\hline Business & 41 & 39 & 21 & 57 & 12 & 21 & $74(37 \%)$ \\
\hline Wage employment & 29 & 27 & 10 & 27 & 14 & 24 & $53(26 \%)$ \\
\hline Home making (housekeeping) & 4 & 4 & 0 & 0 & 0 & 0 & $4(2 \%)$ \\
\hline Arts/talents (theatre and acting) & 9 & 8 & 1 & 3 & 16 & 28 & $26(13 \%)$ \\
\hline Agriculture based & 1 & 1 & 0 & 0 & 3 & 5 & $4(2 \%)$ \\
\hline No core strategy & 21 & 20 & 3 & 8 & 13 & 22 & $37(18 \%)$ \\
\hline No response & 1 & 1 & 2 & 5 & 0 & 0 & $3(2 \%)$ \\
\hline
\end{tabular}

Note: $n=201$

As many as $37(18 \%)$ of youth in the study lacked a primary livelihood strategy before joining youth groups. This implies that the strategies adopted were sporadic. On the other hand, $26 \%$ of the youth reported wage employment as their core livelihood strategy. These worked as casual labourers in craft industries and building sites (kazi ya mjengo), attendants at cybercafé and shops, hairdressers/beauticians, waiters, caretakers of real estate properties and motorcycles riders. Beadwork, painting, acting, craft, training children in martial arts were some of the art and talent-based enterprise strategies adopted by just over a tenth (13\%) of the youth. For a minority (2\%), homemaking (being a housewife) was their core livelihood strategy. Finally, agriculturally based enterprise strategies were not prevalent among youth in the study as only $2 \%$ of youth practised poultry farming and breeding dogs for sale.
Thirty-seven per cent of respondents in the study area practised business as a livelihood strategy. The most common types of business included selling second-hand clothes (mitumba), salon and barber shops, making juice and soap, vending water, motorbike transport service (boda-boda), craft industries (jua kali), installing cable or pay television/digital satellite television, sale of khat (miraa), dealing in scrap metal, reproducing movies and music on compact disks (CDs) as well as hawking pirated digital versatile disks (DVDs).

\section{Typology of Enterprise strategies After Joining Youth Groups}

After youths' membership into groups in Kamukunji Sub-County, the enterprise strategies they undertook were varied as shown in Table 2.

Table 2: Livelihood Strategy after Joining Youth Groups by YLO Levels

\begin{tabular}{lllllllll}
\hline \multirow{2}{*}{ Core livelihood strategy } & \multicolumn{3}{c}{ Survival } & \multicolumn{2}{c}{ Security } & \multicolumn{2}{c}{ Growth } & \multicolumn{2}{c}{ Total } \\
\cline { 2 - 9 } & n & $\mathbf{\%}$ & $\mathbf{n}$ & $\mathbf{\%}$ & $\mathbf{N}$ & $\mathbf{\%}$ & $\mathbf{n}$ & $\mathbf{\%}$ \\
\hline Business & 62 & 59 & 36 & 60 & 22 & 63 & 120 & 60 \\
Wage employment & 24 & 23 & 9 & 15 & 8 & 23 & 41 & 20 \\
Home maker (housekeeping) & 4 & 4 & 0 & 0 & 0 & 0 & 4 & 2 \\
Arts/talents & 9 & 9 & 7 & 12 & 4 & 11 & 20 & 10 \\
Agriculture & 0 & 0 & 3 & 5 & 0 & 0 & 3 & 2 \\
No Primary Strategy & 7 & 6 & 5 & 8 & 1 & 3 & 13 & 6 \\
\hline
\end{tabular}

$n=201$

111 This work is licensed under a Creative Commons Attribution 4.0 International License. 
Three in five youth were engaged in business as a primary livelihood strategy. These businesses included barber and salon shops, car and carpet washing, bakery, craft industries "jua kali", cybercafé, garbage collection, sales promotion, welding, hawking, indoor games entertainment (play station), pest control and fumigation services. A fifth (20\%) of the youth were wage employees, while $10 \%$ practised arts and talents activities such as acting, bead making, martial art instructing, dancing, football, athletics and craftwork. However, despite gaining membership in youth groups, $6 \%$ of the youth had no core livelihood strategy.

\section{A Comparison of Enterprise Strategies before and after Joining Youth Groups}

Study findings revealed that before the respondents joined youth groups, the choice of enterprise strategies was more scattered across a broad spectrum of alternative enterprise strategies (business (37\%), wage employment (26\%), housekeeping (2\%), arts and talents (13\%) and agriculture (2\%) and no core strategy (18\%). The overall majority of youth operated businesses as a livelihood strategy followed by wage employment. Only a few (2\%) female youths undertook housekeeping as a core livelihood strategy which was not affected by their membership in youth groups.

A $62 \%$ increase in the number of youths who chose various businesses as their primary livelihood strategy (from 74 youth before group membership to 120 youth after membership) was noted. The proportion of youth taking up wage employment as a primary livelihood strategy declined by $23 \%$ from 26 to 20 youth after group membership. Similarly, youth choosing a talent-based livelihood strategy witnessed a $23 \%$ decline after group membership. Another remarkable change was the proportion of youth who lacked any form of livelihood strategy, whose percentage reduced by 78 after they joined youth groups.
Relating livelihood strategy typologies with YLOs revealed that before joining youth groups, a majority of youth (57\%) engaging in business were at the security level of YLO. However, after youth group membership, the majority of youth $(63 \%)$ practising business recorded a growth level of YLO. There was a general decline in the percentage of youth taking wage employment after youth group membership. The largest decline was observed among the security and growth levels of YLO. Youth practising arts/talent strategy remained the same for survival, increased (from 3\% to 12\%) for youth in security YLO level and decreased from $28 \%$ to $11 \%$ for youth in growth YLO level after youth group membership. The number of youths who reported, "no primary strategy" decreased drastically among youth in survival and growth YLO levels.

Evidence shows that coefficients are not jointly different from zero. Besides, the low pseudo-Rsquared of 0.0359 was established which indicates that youth enterprise strategies improve model prediction power of YLO by only $4 \%$. Interpreting coefficients of specific independent variables, youth who undertook wage employment as opposed to business livelihood strategy before joining youth groups had $4 \%$ higher odds of attaining better livelihood outcomes, ceteris paribus than business owners. These odds were lower by $27 \%$ among wage employee members of youth groups than business owners. Youth who chose homemaking as a livelihood strategy prior to group membership had $55 \%$ lower odds of attaining better livelihood outcomes; the odds were $3 \%$ higher among youth group members, holding other variables constant.

The odds of attaining better levels of youth livelihood outcome were 1.72 higher among youth who practised arts/talent before joining youth groups which increased to $86 \%$ after youth group membership. The odds of achieving better livelihood outcomes were two times better among youth whose strategy was agriculture rather than a business after membership in youth groups. On the

112 | This work is licensed under a Creative Commons Attribution 4.0 International License. 
other hand, odds of achieving better livelihood outcomes decreased among youth with no strategy more than among those in business, assuming other variables remained constant.

$H_{01:}$ The enterprise strategies adopted by youth do not significantly influence livelihood outcomes
The LR $\chi^{2}$ statistic and pseudo $\mathrm{R}^{2}$ from ordered logistic regression were used. An insignificant LR $\chi^{2}=12.32$ (d.f. $\left.=12 ; \rho>0.05\right)$ was established as shown in Table 3.

Table 3: Ordinal logistic regression of YLOs against livelihood strategy typology

\begin{tabular}{|c|c|c|c|}
\hline \multirow[t]{2}{*}{ Predictor } & \multicolumn{3}{|c|}{ Estimated Coefficient } \\
\hline & Odds Ratio $(\beta)$ & Significance $(p>Z)$ & Z Statistic \\
\hline \multicolumn{4}{|c|}{ Livelihood strategy typology before joining youth group (base: Business) } \\
\hline Wage employment & $1.043^{*}$ & 0.020 & 2.31 \\
\hline Home making & 0.454 & 0.498 & -0.68 \\
\hline Arts/Talent & $1.720^{*}$ & 0.037 & 1.98 \\
\hline Agriculture based & 0.974 & 0.131 & 1.26 \\
\hline None & 0.837 & 0.767 & -0.3 \\
\hline \multicolumn{4}{|c|}{ Livelihood strategy typology after joining youth group (base: Business) } \\
\hline Wage employment & $0.735^{*}$ & 0.048 & -2.05 \\
\hline Home making & 1.034 & 0.916 & 0.11 \\
\hline Arts/Talent & $1.856^{*}$ & 0.041 & 1.97 \\
\hline Agriculture based & 2.101 & 0.496 & 0.68 \\
\hline None & 0.932 & 0.931 & -0.09 \\
\hline Pseudo R-Squared & 0.0359 & & \\
\hline Log likelihood (Iteration 4) & -165.50212 & & \\
\hline LR chi2(12) & $12.32^{*}$ & 0.0502 & \\
\hline Obs (n) & 198 & & \\
\hline /cut1 & 0.360123 & & \\
\hline /cut2 & 2.440747 & & \\
\hline \multicolumn{4}{|c|}{$\begin{array}{l}\text { LR means Likelihood Ratio *and **indicate that parameters attained significance at } 5 \% \text { and } 1 \% \text { tes } \\
\text { levels }(p<0.05 \text { and } p<0.01)\end{array}$} \\
\hline
\end{tabular}

Business livelihood strategy (salon, bodaboda, hawking, car wash, garbage collection, among others) was used as the base for analysis of the influence of livelihood strategy typology on YLOs

From the results in Table 3, an insignificant LR $\chi^{2}=$ 12.32 (d.f. $=12 ; \rho>0.05$ ) is attained. Evidence lacks to show that coefficients are jointly different from zero (or $\beta_{\mathrm{i}} \neq 0$ ). Hence the intercept-alone model can adequately estimate youth livelihood outcome levels without the need for predictors estimating youth enterprise strategies. Besides, the low pseudo$\mathrm{R}$-squared of 0.0359 is established which indicates that youth enterprise strategies improve the prediction power of YLO by only $4 \%$.

The hypothesis that posited no relationship between youth enterprise strategies and their livelihood outcomes was sustained.

113 | This work is licensed under a Creative Commons Attribution 4.0 International License. 


\section{DISCUSSION}

\section{Typologies of Enterprise Strategies by Youth Livelihood Outcomes}

The study investigated the influence of youth enterprise strategies on YLOs by establishing the core enterprise strategies that youth undertook before and after joining youth groups. These enterprise strategies were grouped into broad categories of wage employment, business, homemaking, arts/talent and agriculture-based. Wage employment and arts \& talent were significant predictors of youth livelihood outcomes. Arts and talents provided a quick source of nonwage income for some youth. The study notes that before youth joined groups, the choice of enterprise strategies was more scattered across the broad alternative enterprise strategies (business, wage employment, housekeeping, talents, agriculture or no-strategy). After group membership, the choice of enterprise strategies clustered around business, wage employment and talent-based activities. Wage employment provided a stable and reliable income source while arts and talents were greatly used by youth in groups and supported by intervention programs by non-state actors as a readily available livelihood strategy option among youth.

The majority of youth in the study operated in the informal sector of the economy mainly because of a lack of formal jobs, inadequate skills and entrepreneurship opportunities. These findings are supported by a study in Isiolo, Kenya by Kiyana and Gitonga (2018), which pointed out that lack of opportunities for formal employment has led many youths to join the informal sector, whose performance depends much on the health of the economy. A study carried in Kenya also noted that over the past decade, there has been a steady shift from formal to informal sector employment, commonly referred to as "Jua Kali" (United Nations Development Programme, 2013). In addition, these findings concur with studies in Nigeria which indicated that youth undertook informal employment opportunities as enterprise strategies in order to survive. Ezeah's study (2012) highlights that urban youth in Nigeria utilised a mix of economic and social strategies. Economically, youth engaged in informal activities such as newspaper vending, food processing and sales, fashion and designing, hairdressing, music vending, motorcycle transport and selling mobile phones. Despite diversifying into the informal sector after joining different youth groups, the results indicate that this did not result in significant positive livelihood outcomes for the youths. The informal sector is largely unregulated and subjects the youth to hazardous conditions for low earnings and long working hours without any formal contract (ILO, 2020). In Ghana, according to Odoom (2011), youth survive through their engagement in the informal sector, becoming part of the urban poor.

Enabling youths to become entrepreneurs can play a critical role in tackling youth unemployment, but these need to go hand in hand with empowerment. Although there is increasing recognition of its social multiplier effect and economic potential, young people continue to face significant barriers in entrepreneurship, in particular, lack of access to finance, weak enterprise culture and inadequate education (Sakyiamah, 2015). Funding is required for lending to the youth, artisan and business management skills and equipment of training institutions. Youth need knowledge, essential skills, competencies and opportunities to engage in microsmall and medium enterprises and self-employment mechanisms.

Specifically, the study established that after youth gained membership in youth groups, the majority of them adopted the business strategy, particularly among youth in survival and growth levels of livelihood outcomes. There was a decrease in dependency on talent-based enterprise among youth in the study. The number of youths seeking employment and also those with no livelihood strategy across youth in survival, security and growth levels of YLO decreased. The majority of 
youth in groups perceived their livelihoods positively because they appreciated that without the enterprise strategies they undertook, life would be unbearable in the urban slum setting of Kamukunji.

It emerged that within youth groups, youths were able to share about challenges they faced in deriving livelihoods, dreams, aspirations and drew advice from and even cushioned each other against shocks and seasonality. This meant that youth groups could be an effective vehicle to reduce idleness and vulnerability among youth. Similar findings were reported among youth in poor urban settings in Nigeria (Ezeah, 2012). The key challenge therefore as for many developing countries including Kenya is to identify strategies that can generate income opportunities through decent work in return reducing unemployment and underemployment in the informal sector (Obare, 2015).

\section{CONCLUSION}

Youth livelihood outcomes did not differ by typology of livelihood strategy undertaken by youth. This finding is of fundamental importance since it indicates that none of the enterprise strategies adopted was better aligned than others to improve youth livelihood outcomes. Thus, none of the strategies can be exclusively preferred for policy implementation. The study, therefore, recommends that Youth Focused Intervention programmes by the Ministry of Public Service, Youth and Gender Affairs, and Non-Profit Organisations should target all typologies of enterprise strategies that youth undertake to ensure that all youth are able to achieve higher livelihood outcomes. The study also recommends that there is a need to have elaborate and expansive business incubation and mentorship programmes for youth by State and Non-Sate Actors so as to ensure the youth groups have continued lifespan so that through sustained membership, the youth are able to enhance their livelihood outcomes.

\section{ACKNOWLEDGEMENTS}

The authors appreciate the support from the participants in this study.

\section{AUTHORS' CONTRIBUTIONS}

The first and second authors participated in the research process from research conception to the development of research tools, data collection, analysis and writing of the research report.

\section{REFERENCES}

Arkoh, D. (2019). Assessing unemployment and livelihoods: perspectives of urban youth. Jyväskylä University

DFID. (1999). Sustainable livelihoods guidance sheets. London: DFID

Elder, S., \& Rosas, G. (2015). Global employment trends for youth 2015: Scaling up investments in decent jobs for youth. International Labor Organization.

Ezeah, P. (2012). Youths' poverty and livelihood strategies in Fegge, Onitsha Urban Local Government Area, Nigeria. Bourdillon, MF C. and Sangare, A. (Eds.), Negotiating the livelihoods of children and youth in Africa's urban spaces, 123-134.

Filmer, D., \& Fox, L. (2014). Youth employment in sub-Saharan Africa. World Bank Publications.

International Labour Office. (2012). Global employment trends for youth 2012. ILO Publications.

International Labour Organisation (ILO). (2020). COVID-19 and the World of Work: Country Policy Responses. International Labour Organisation

Kenya National Bureau of Statistics. (2019). The 2019 Kenya Population and Housing Census:

115 | This work is licensed under a Creative Commons Attribution 4.0 International License. 
Population by County and Sub-county. Kenya National Bureau of Statistics.

Kiyana, M. D., \& Gitonga, A. K. (2018). Determinants of youth enterprise development funded projects performance in Isiolo County. International Academic Journal of Information Sciences and Project Management, 3(2), 186-207.

Krueger, R. A. (2014). Focus groups: A practical guide for applied research. Sage publications.

Marable, M. (2015). How capitalism underdeveloped Black America: Problems in race, political economy, and society. Haymarket Books.

Mwaura, G. M. (2015). Educated youth in Kenya: Negotiating waithood by greening livelihoods (Doctoral dissertation, University of Oxford).

Njonjo, K. S. (2010). Youth fact book: Infinite possibility or definite disaster? Institute of Economic Affairs (IEA) and Friedrich-EbertStiftung (FES).

Obare, M. J. (2013). The Impact of Informal Economy on Employment Creation: The Case of Kamukunji Jua Kali Artisans in Nairobi (Doctoral dissertation, University of Nairobi,).

Obeng-Odoom, F. (2011). The informal sector in Ghana under siege. Journal of Developing Societies, 27(3-4), 355-392.

Rakodi, C. (2016). The urban challenge in Africa. In Managing urban futures (pp. 63-86). Routledge.

Republic of Kenya, (2011a). Economic Survey. Nairobi: Government Printer.

Republic of Kenya, (2011b). Second Annual Progress Report on the Implementation of the
First Medium Term Plan (2008-2012). Nairobi: Monitoring and Evaluation Directorate, Ministry of State for Planning, National Development and Vision 2030.

Sakyiamah, B. S. (2015). An Assessment of the Effects of the Ghana Youth Employment and Entrepreneurial Development Agency Programme on Beneficiaries in the Dormaa East District of the Brong Ahafo Region (Doctoral dissertation).

Serrat, O. (2017). The sustainable livelihoods approach. In Knowledge solutions (pp. 21-26). Springer, Singapore.

Stewart, D. W., \& Shamdasani, P. N. (2014). Focus groups: Theory and practice (Vol. 20). Sage publications.

Tuckman, B. W. (1965). Developmental sequence in small groups. Psychological bulletin, 63(6), 384.

United Nations Development Programme (UNDP), (2010). Kenya National Human Development Report 2009: Youth \&Human Development Tapping the Untapped Resource, Kenya.

UNDP, (2013). Kenya's Youth Employment Challenge. New York.

UN-Habitat, (2013). State of the Urban Youth Report 2012-2013: Youth in the Prosperity of Cities. Nairobi, Kenya.

United Nations. (2018). World youth report: Youth and the 2030 agenda for sustainable development. Department of Economic and Social Affairs, United Nations Publications.

116 This work is licensed under a Creative Commons Attribution 4.0 International License. 